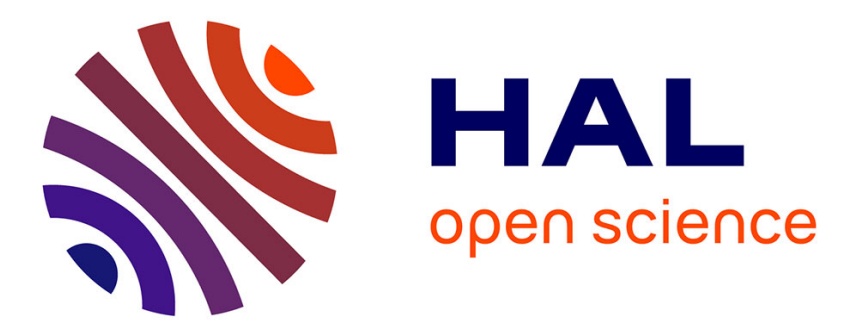

\title{
Gravimetric evidences of active faults and underground structure of the Cheliff seismogenic basin (Algeria)
}

Abdesslam Abtout, Hassina Boukerbout, Boualem Bouyahiaoui, Dominique Gibert

\section{- To cite this version:}

Abdesslam Abtout, Hassina Boukerbout, Boualem Bouyahiaoui, Dominique Gibert. Gravimetric evidences of active faults and underground structure of the Cheliff seismogenic basin (Algeria). Journal of African Earth Sciences, 2014, 24 th colloquium of African geology, 99 (2), pp.363-373. 10.1016/j.jafrearsci.2014.02.011 . insu-01185058

\section{HAL Id: insu-01185058 https://hal-insu.archives-ouvertes.fr/insu-01185058}

Submitted on 19 Aug 2015

HAL is a multi-disciplinary open access archive for the deposit and dissemination of scientific research documents, whether they are published or not. The documents may come from teaching and research institutions in France or abroad, or from public or private research centers.
L'archive ouverte pluridisciplinaire HAL, est destinée au dépôt et à la diffusion de documents scientifiques de niveau recherche, publiés ou non, émanant des établissements d'enseignement et de recherche français ou étrangers, des laboratoires publics ou privés. 
Gravimetric evidences of active faults and underground structure of the Cheliff seismogenic basin (Algeria)

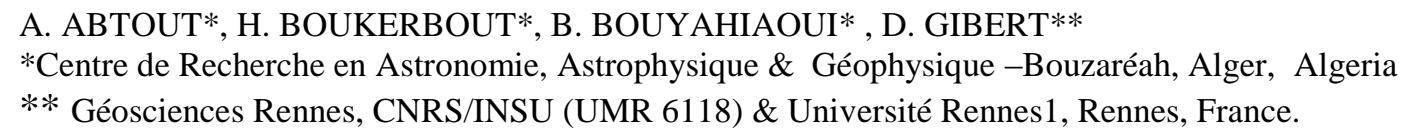

\section{Abstract}

The Cheliff basin (ex El Asnam) is known as one of the most seismic active zone in Algeria and the West Mediterranean region. We can cite the El Asnam earthquake which occurred in 10.10.01980 with magnitude of 7.3. It was generated by a thrust fault with NE-SW sinistral component. Until now, there is a little information about existence of deep active faults, which generate this strong activity. The gravity field is an important resource of information on crustal structure. The aim of this work is giving a reliable geometry of the major faults relative to the kinematics of this region.

The results obtained from various filtered maps (derivatives, upward continuation) of the gravity data, were used to generate a structural map of the studied area. Whilst the continuous wavelet transform method can help in automatic detection of elongated structures in $3-\mathrm{D}$, to estimate their strike direction, shape and depth. It gives a 3-D image or a model of the region and confirms the existence of several faults, localised or inferred, from former geological studies.

Keywords: Gravity anomalies, Cheliff basin, continuous wavelet transform 3-D image, deep structures, faults and contacts, structural map.

\section{Introduction}

This work is carried out under the CMEP Project (Comité Mixte d'Evaluation et de Prospective) which is about a geophysical and geological study of the seismogenic Cheliff basin. In this study we aimed at bringing a little contribution to try to understand and placing the studied area in a regional geodynamic context. This work concentrates on the relationships between the various geological formations that are clearer in the basin and those bounding the area and, especially the geometry of the faults at depth in relation to a general tectonic context. It is based on gravity analyses correlated with complementary geological and seismological information. The use of the continuous wavelet transform allows establishing a 3-D image of the region depicting thus a great number of deep or near surface faults and contacts that had remained unknown until the present time. 
The studied area is situated in a box ranging from $01^{\circ} 00^{\prime}-01^{\circ} 46^{\prime}$ in longitude and $36^{\circ} 00^{\prime}-$ $36^{\circ} 36^{\prime}$ in latitude. The region displays a complex geological setting (Figure 1) and, its shallow seismicity is considered as diffuse because it spreads over a wide zone, instead of indicating a single major fault (Meghraoui et al., 1996) (Figure 2). It is bounded in the North by the Mediterranean Sea and in the South by the Ouarsenis Mountains which are constituted by allochtonous lower Jurassic and Cretaceous formations. In the middle of the area, the E-W Mio-Plio-Quaternary intra-mountainous "post-thrust" Cheliff basin overlays an ante-Neogene basement consisting of Mesozoic series. It is a consequence of the distension phase that occurred during the Lower-Middle Miocene (Anderson, 1936; Perrodon, 1957). The E-W form of the basin implies N-S to NNW-SSE compressional movements (Meghraoui et al., 1986). The structure of the Cheliff basin is the result of the Alpine orogen (Perrodon, 1957). The neotectonics studies show that the main deformation is a NNW-SSE compression which is related with overthrusting reverse faults and strike-slips (Groupe de Recherche néotectonique de l'arc de Gibraltar, 1977; Philip and Thomas, 1977); this is confirmed by the studies of African plate movements (Philip and Thomas, 1977; Minster and Jordan, 1978; Anderson and Jackson, 1987) and focal mechanisms of the seismic events of 1954 and 1980 (Ouyed et al., 1981).

The main tectonic phases involving the formation of the basin is the subsidence in the Late Burdigalian followed by an extensional phase in Lower Tortonian with development of graben structures (Meghraoui, 1982). An important NNE-SSW compressive phase deformed the Miocene formations (Meghraoui et al, 1986). In the Quaternary, a second important compression phase occurred, with a NNW-SSE to NW-SE shortening direction and affected the Quaternary deposits (Meghraoui, 1982). The present deformation in the Cheliff basin is mainly related to a transpression with N-S to NNW-SSE shortening direction, which is expressed by active tectonics responsible of the earthquake activity (Philip \& Meghraoui, 1983, Meghraoui et al., 1986). The NE-SW trending folds and NE-SW active sinistral transpressive faults were activated during the 1954 and 1980 destructive earthquakes (Bezzeghoud et al., 1995; Ouyed et al., 1981). These reverse faults and related folding are disposed on right lateral echelon and should be coupled with NW-SE to E-W trending strikeslip deep active faults (Meghraoui, 1982, 1986, 1988; Thomas, 1985; Chiarabba et al, 1997). The NE-SW faults are associated with asymmetric folds and the different tectonic structures define some NE-SW blocks (Morel \& Meghraoui, 1996). A kinematics model of block rotation related to a transpression with NNW-SSE direction of plates convergence is proposed 
in the Cheliff basin (Meghraoui et al., 1996) where the blocks rotation was previously studied with paleomagnetic investigations by Aiffa et al., 1992 and recently by Derder et al., 2011. This work complements information on some of them and outlines especially those very deep. In the studied area, the Moho discontinuity is at about $30 \mathrm{~km}$ deep (Hatzfeld, 1978). This region is integrated in a set of complex zone, in the Western Mediterranean Sea, where are observed series of negative and positive gravity anomalies (Gourinard, 1958; Van Den Bosch, 1971; Galdeano et al., 1974; Bellot, 1985).

The analysis of the latest gravity survey carried out in the Cheliff region outlines a significant density contrast in the South part of the basin, elongated in the NE-SW and NW-SE directions (Abtout et al., 2009), which may be interpreted as a contact between the sediments up to Cretaceous age of the regional stratigraphical series and the Neogene deposits of the basin. Furthermore, detailed aeromagnetic data analysis of the Cheliff region, including the Cheliff basin (Boukerbout et al., 2008) sketch out the presence of two major very deep E-W structures localized in the North (Mediterranean Sea and along the coast) and in the South of the "Cheliff" basin (Ouarsenis Mountains). Their depth is ranging between 29 and $31 \mathrm{~km}$. The orientation of these bounding structures does not correspond to the direction of the present active faults which is mainly NE-SW.

\section{Gravity measurements and Bouguer anomaly map}

The gravity data were collected in different surveys carried out in this area. The data distribution is not homogeneous, with a lack of information close to the coast. The distribution of land measurement is irregular. It is around $0.5 \mathrm{~km}^{-2}$ in the Cheliff basin, except in the inaccessible regions where the distribution reaches $1 \mathrm{~km}^{-2}$. However, this distribution is generally sufficient for our targets.

Therefore, all the gravity data were homogenized by linking them to the Bouzaréah station, which belongs to the Algerian absolute gravity network. The data were uniformly reduced with a density of $2.400 \mathrm{Kg} \mathrm{m}^{-3}$ for the Bouguer correction which is the mean density of the quaternary formations, determined analytically with the use of the triplets method. The topographic reduction was computed with the same uniform density and with a radius of 20 $\mathrm{km}$.

The Bouguer gravity map of the studied area was produced by interpolating the entire data to $0.25 \mathrm{~km}$ grid spacing. Several interpolation methods were tested, and as there were no significant differences in the resulting maps, the minimum curvature algorithm was used to set up the grids that were used as a basis for later analysis. 
Preliminary analysis of the Bouguer anomaly map determine the gravity signature of key features such as the geometry of the major faults, the identification and location of the geological structures and the sedimentary basin. The map (Figure 3) shows two distinct major sets: in the North, positive anomalies oriented ENE-WSW, mainly due to the effect of the oceanic nature of the Mediterranean crust (Auzende et al., 1973; 1975), while in the South, appears the negative effect of the roots of the Ouarsenis Mountains. In the central part, a series of negative anomalies located on Mio-Plio-Quaternary terrains, trending in the NE-SW direction and corresponding to the Cheliff basin effect.

\section{Interpretation and discussion}

\subsection{Identification of gravity features}

To emphasize gravity contrasts on the Bouguer anomaly map (Figure 3), some automatic structural analysis were undertaken. This kind of analysis is suitable for defining discrete borders of causative bodies at depth. To underline the short wavelength anomalies which reflect the signature of shallow or sub-outcropping geological structures, the technique of shading the anomaly map is used (Figure 4); the advantage of this method is that it doesn't modify the strength of the high frequency signature, but, as the illumination is directional, certain anomalies may be unfavourably illuminated and thus not show up. This technique is particularly useful for enhancing subtle linear features, which may be related to geological structures. It introduces a directional bias in that features which lie perpendicular to the light source are emphasized whilst those parallel to it are subdued (McDonald et al., 1992). The shaded relief image of Figure 4 enhances features with a northwesterly trend which don't appear on the Bouguer anomaly map. Moreover, the residual anomaly (Figure 5) is computed. It is the Bouguer anomaly values minus corresponding values on the second-order polynomial surface (trend) obtained by least square. The vertical gradient is computed using the Fourier transform of the gravity field (Gerard and Griveau, 1972). The vertical gradient (Figure 6) is used to recognize local and shallow features, while, the residual (Figure 5) underlines the contacts between geological structures with contrasting densities. As well, to separate between long wavelength and short wavelength anomalies the upward continuation method is applied on data (Figure 7).

136 The analysis of gravimetric maps (Figures 3 - 7), show a succession of negative anomalies, in

137 the central part of the map, corresponding to the effect of the Cheliff basin and located on

138 Mio-Plio-Quaternary terrains. More details appear on the shaded map (Figure 4), which were 
not identified on the Bouguer anomaly map, such as those anomalies trending in the NW-SE direction, in the Cheliff basin and, in NNE-SSW direction in the North.

First kind of gravity discontinuities are related to specific geological structures (Figure 5), such as the positive anomalies in the South, which are located above Cretaceous formations covered partially by Tortonian post-nappes formations. At the East, two positive anomalies located on the Temoulga and Rouina massifs correspond to the Jurassic substratum. Second kind of discontinuities emphasizes the main gravity gradient of the area (Figure 6). In general, these several discontinuities follow known and unknown faults and contacts.

On these two latter maps, appear in the Cheliff basin a series of three anomalies trending from the NE-SW direction, in the western part of the basin, to the E-W direction in its eastern part. From West to East, these three individualised blocks are limited by the Boukadir fault, El Asnam fault and Oued Fodda fault.

The positive anomalies in the South are separated from the negative anomalies within the basin by two NE-SW discontinuities corresponding probably to the Relizane and El Asnam Faults, as shown on the geological map. The negative anomalies in the West of the Cheliff basin are separated by a NE-SW discontinuity corresponding to the Boukadir Fault. In addition to these discontinuities, appear two irregular contacts, in the opposite direction, trending in the NW-SE direction and distort negative anomalies in the West. The first irregular contact is thrusting the Cheliff basin in dextral way and the second one close or limits the basin and the raised basement (Mattauer, 1958; Kireche, 1977; Idres et al., 1996).

The examination of the upward continued maps at 2, 3, 4 and $5 \mathrm{~km}$, show that the most negative anomalies within the basin disappear on the upward continued map at $3 \mathrm{~km}$ (Figure 7) while the positive ones in the central part and the negative one in the western part of the basin persist until the continuation at the altitude of $5 \mathrm{~km}$. This suggests that the thickness of the Cheliff basin is not flat and can be estimated between 3 and $5 \mathrm{~km}$.

\subsection{Estimation of the depth}

The most important application in potential fields analysis is the determination of the depth and the shape of the anomalies causative structures. It is also the most frequent problem encountered in interpretation, especially in determining the geometry of geological bodies responsible of field anomalies, at depth. So, there were and still are too many processing methods developed and suggested in potential field theory, to try to solve this problem. Among these investigation methods, there is modeling the observed anomalies which leads to a representation of simple geometrical interfaces such as geological contacts related to depth. 
173 Idres et al., (1998) attempted to model along profiles crossing the anomalies in the NW of

174 Cheliff basin. However, the modeling approach has led up to a variety of different inversion 175 algorithms (Cuer and Bayer, 1980; Tarantola, 1987; Parker, 1994; Li and Oldenburg, 1996) 176 depending on their ability to tackle with geological prior constrains to reduce the nonuniqueness of solution (Pilkington, 1997; Bosch et al., 2001). On the other hand, numerous analyzing methods, which do not belong to the inverse methods family defined above, were developed. They transform the measured field and allow identifying and characterizing the sources responsible of the observed anomalies. For instance, empirical graphical techniques were proposed for determining the depth related to magnetization distribution of defined shapes (Peters, 1949). Other methods based on the use of synthetic model fitting were proposed, such as Werner deconvolution (Werner, 1953; Hartman et al., 1971), Euler deconvolution (Thompson, 1982; Reid et al., 1990) and analytical signal (Naighian, 1972; Roest et al., 1992; Nabighian et al., 2005). Developments and improvements of these methods which assume a selected geometry of the source, have been realized, such as the application of clustering technique for selecting appropriate solution in Euler deconvolution method (Mikhailov et al., 2003), the use of vertical gradients (Marson and Kligele, 1993; Debeglia and Corpel, 1997) and the study of the noise effect in data (Keating, 1998). Other methods derived from Euler deconvolution and analytic signal to recover the shape and the depth of the sources (Huang, 1996; Stavrev, 1997; Barbosa et al., 1999; Hsu et al., 1998) or the source parameter imaging method (Thurston and Smith, 1997) based on the use of the local wavenumber function (Smith et al., 1998; Thurston et al., 2002; Smith and Salem, 2005; Pilkington and Keating, 2006; Salem et al., 2005; 2008).

In this work, to localize bodies causing gravity anomalies, we use the method based on the continuous wavelet transform. More than localization, the method leads to an image of structures in 3-D. This method simplifies the analysis of large amounts of data (e.g., Arneodo et al., 1995; Holshneider, 1995; Torresani, 1995; Mallat, 1999). Many developments were performed since the first paper of Moreau et al. (1997), where the basic principles exploit the homogeneity properties of potential fields to localize and identify sources of the anomalies. The homogeneous degree quantifies the shape and can be compared to the structural index defined in Euler deconvolution (Sailhac et al., 2000; Sailhac and Gibert, 2003). The wavelet domain is the upward continuation domain of derivatives and gradients (Moreau et al., 1999; Hornby et al., 1999; Vallée et al., 2004), Hilbert transforms and analytic signal (Sailhac et al., 2000; Martelet et al., 2001). The wavelet theory is efficient to deal with noise (Moreau et al., 1999; Sailhac and Gibert, 2003) as it was shown through different applications to gravity data 
(Martelet et al., 2001; Fedi et al., 2004), aeromagnetic data (Sailhac et al., 2000; Boschetti et

208 al., 2004) and electromagnetic data (Boukerbout et al., 2003). A review of the theory of the continuous wavelet transform in the interpretation of potential fields, with major references, can be found in the article of Sailhac et al., (2009). Then, the 2-D wavelet method was developed (Boukerbout and Gibert, 2006) to analyze elongated anomalies produced by geological features such as faults, contacts or prismatic bodies, by the use of the ridgelet functions (Candès, 1998) and the maximum entropy criteria (Tass et al., 1998; Boukerbout et al., 2003) for selecting sources location. A detailed method with synthetic example and application on aeromagnetic data can be found in the paper of Boukerbout and Gibert (2006), where it is also shown through this application, that the ridgelet depths are in agreement with Euler depths and, better than Euler method provide a sharper determination for large depths. In the Cheliff basin, the structures responsible of gravimetric anomalies are shown in (Figure 8). It is clear that the Cheliff basin is limited in its northern and southern parts, by elongated structures (1, 2, 3 and 4) with a general trending in the E-W direction. The first structure limiting the Cheliff basin, in the North, is made of three segments (1,2 and 3). In the West, the segment (1) is about $36 \mathrm{~km}$ long; related to Tortonian and Pliocene and upper Miocene formations (Figure 1) at a depth of $z=0 \mathrm{~km}$ and reaching the depth of $2 \mathrm{~km}$. The second (2) and the third (3) parts of the E-W structure, in the middle and the East part of the basin, are associated to Tortonian and Messinian formations, and are more deep, in its northern part, the depth from $4 \mathrm{~km}$ to $14 \mathrm{~km}$ and in the middle of the basin, it reaches the depth of $16 \mathrm{~km}$. The second structure (4) limiting the Cheliff basin, in its southern part, is associated to Neogene and Tellian substratum, is long about $59 \mathrm{~km}$ and at a depth varying from $0 \mathrm{~km}$ to $9 \mathrm{~km}$. These E-W structures are crossed by some N-S ones, limiting thus the Cheliff basin in its eastern and western parts. In the West of the Cheliff basin, the N-S structure (5), identified near the Dahra, associated to Neogene and Tellian substratum and Pliocene and upper Miocene formations, is long about $27 \mathrm{~km}$ and located at a depth varying from $0 \mathrm{~km}$ to $5 \mathrm{~km}$. Eastward of the Cheliff basin, the N-S structure (6), is about $18 \mathrm{~km}$ long. It is located nearby Quaternary formations and Neogene and Tellian substratum, between the Boumaad and the Doui massifs and reaches $4 \mathrm{~km}$ of depth. At the left side of this structure, another NNW-SSE structure (7), appears composed of two parts, long about $22 \mathrm{~km}$ and $18 \mathrm{~km}$, reaching $8 \mathrm{~km}$ in the South and $11 \mathrm{~km}$ in its northern part, corresponding to the centre of the Cheliff basin. These structures cross the E-W structures (1, 2, 3 and 4) limiting the Cheliff basin, and particularly, in the centre of the basin, near Oued Fodda zone, where it shifts the E-W 
Cheliff basin, appear two NE-SW structures. The first one (8), long about $23 \mathrm{~km}$, is located nearby the Boukadir anticline, in the same direction of the Boukadir fault, but more deep, between $7 \mathrm{~km}$ and $10 \mathrm{~km}$. Northward of this structure, is identified the second NE-SW one (9). It is related to the anomalies laying over Neogene and Tellian substratum and Pliocene and upper Miocene formations, in the limit South of the Dahra massif. Its depth varies from 1 $\mathrm{km}$ to $11 \mathrm{~km}$. This structure continues until the North of the studied area, near the Tenes region and reaches the $8 \mathrm{~km}$ of depth. It is shifted by the E-W structure (10) which depth varies from $4 \mathrm{~km}$ to $8 \mathrm{~km}$. A NW-SE (11) structure connect the two latter NE-SW (8 and 9) structures in the West of the Cheliff basin, it is composed of two parallel segments. The first one is located at a depth ranging between $1 \mathrm{~km}$ and $2 \mathrm{~km}$, and the second one, between $4 \mathrm{~km}$ and $11 \mathrm{~km}$. Another NW-SE (12) structure appears in the East of the Cheliff basin, overhanging the set of E-W, N-S and NNE-SSW structures. This structure is shallower and is identified between $0 \mathrm{~km}$ and $4 \mathrm{~km}$ of depth. In the North of the region, appears the E-W structure (10), near the coast, corresponding to the analysis of anomalies located over volcanic formations and Neogene and Tellian substratum, in the Tenes region, long about $30 \mathrm{~km}$ and reaching $8 \mathrm{~km}$ of depth. Eastward of this structure, appears a NE-SW structure (13), at a depth reaching $5 \mathrm{~km}$. All the identified structures at shallow depth outline the majority observed or supposed faults and contacts as shown in the geological map (Figure 1), except for some N-S, E-W, NW-SE structures and of course those very deep. These results may complete the structural map of the area and, a summary of the different gravimetric features outlined in this study from different analyzing methods are reported on the shaded map in figure 9 . The shape achieved by gravity lineaments as identified and outlined on the shaded map, agrees with the theory of the structure in blocks of the Cheliff basin (Thomas, 1985; Morel and Meghraoui, 1996). It is shown from the correlation with the seismicity of the area (Figure 10), that majority of identified structures are located on active zones. As it is shown on this map, the seismicity of the region is diffuse and has no preferential direction. The superimposing of the identified structures on the seismicity map shows at first a good correlation with the known faults such as Boukadir fault, Oued Allalh fault, Dahra fault, Oued Fodda fault. However, there are many identified structures which are correlated with seismicity by creating a preferential tendency of the seismicity while there is no geological information identifying these structures. We can cite for example the identified structures creating an E-W trending of the seismicity, in the centre and the South of the basin. These structures are located in the regions of El Abadia - Chlef in the centre of the basin and in the South it is located near the 
structure is elongated in the NW-SE direction and is located in the area Oued Sly - Tadjenna. Finally, this correlation allows us to make trend of the seismicity of the area and the lack of the geological information about these structures is probably due to the fact that these structures are too deep.

\section{Conclusion}

The Bouguer anomaly map of the Cheliff shows two main distinguished sets of anomalies. The first set of positive anomalies in the North, corresponding to oceanic crust of the Mediterranean Sea. The second set of negative anomalies in the South, corresponding to the effect of the roots of the Ouarsenis Mountains. Over the Mio-Plio-Quaternary terrains of the Cheliff basin, lays a succession of NE-SW anomalies corresponding to the basin effect. Automatic structural analyses enhance more details that were not observable on the Bouguer map, such as the NW-SE positive anomalies in the Cheliff basin and in the North and suggest that the thickness of the Cheliff basin is not constant and flat. Different discontinuities and gravity lineaments identified show good correlation with known geological structures, such as the positive anomalies, where in the South correspond to Cretaceous formations and in the East correspond to the Jurassic substratum. These latter were separated from the negative anomalies within the basin by NE-SW discontinuities corresponding to known faults such as the Relizane and El Asnam faults, while the negative anomalies in the West of the basin are separated by the Boukadir fault which trends in NE-SW direction. In the NW-SE direction appear two contacts, not identified in geology, the first one thrust the basin in dextral way and the second one bound the basin and the raised basement in the South, which was explained by different authors by an indenter which may have reoriented the Cheliff basin in its southern boundaries. Elongated and deep structures are identified in the North and the South of the basin, trending in the E-W direction. In North, this structure is deeper in the central part and eastward of the basin than at its West. It reaches $16 \mathrm{~km}$ of deep, while in the South it attains 8 $\mathrm{km}$. The summary of the identified features as outlined on the shaded map, from different analyses methods and the ridgelet transform, show geometrical shape of structures delineated into different polygonal forms, at large and local scales. This organization goes in the same way as the theory of the structure in blocks of the Cheliff basin, as defined by many authors. Also, the correlation with seismicity, shows that majority of identified gravity features are located on active zones. On the other hand, many identified features are not recognized by known geological structures and especially, those very deep, which remain unresolved. So, 
this map contributes to the geological interpretation in regions where not much subsurface

309 information exists.

\section{Acknowledgements}

312 This work was supported by CMEP Project $\mathrm{N}^{\circ}$ 08MDU752 and benefited from discussions 313 with our colleagues. We are grateful to the reviewers for their remarks to improve this work.

314 We thank M.E.M Derder, B. Henry and S. Maouche for the useful and constructive 315 discussions.

\section{References}

Abtout, A., Boukerbout, H., Bouyahiaoui, B., Gibert, D. \& Derder, M.E.M., 2009. Gravity anomalies and structure of Cheliff seismogenic basin (Algeria). International Earthquake Symposium Kocaeli, Turkey, 17-19 August 2009.

Aïfa, T., Feinberg, H., Derder, M.E.M. \& Merabet, N., 1992. Rotations paléomagnétiques récentes dans le bassin du Chéliff (Algérie). Comptes Rendus de l'Académie des Sciences Paris, 314, SII, 915-922.

Anderson, R.V., 1936. Geology in the coastal atlas of western Algeria. Memoir Geological Society of America, 4, $450 \mathrm{p}$.

Anderson, H., Jackson, J., 1987. Active tectonics of the Adriatic region. Geophys. J. R. astr. Soc., 91, 937-983.

Arneodo, A., Argoul, F., Bacry, E., Elezgaray, J., and Muzy, J.F., 1995. Ondelettes, multifractales et turbulences, de 1'AND aux croissances cristallines. Diderot Editeur, Paris, 184 pp. ISBN 2-84134-024-4.

Auzende J., Bonnin, M., Olivet, J.L., 1973. The origin of the western Mediterranean Basin, J. Geol. Soc. Lond.129 607-620.

Auzende, J., Bonnin, M., Olivet, J.L., 1975. La marge Nord-Africaine considérée comme marge active. Bull. Soc. Géol. France, 22, (4), 486-495.

Barbosa, V.C.F., Silva, J.B.C., and Medeiros, W.E., 1999. Stability analysis and improvement of structural index estimation in Euler deconvolution. Geophysics, 64, 48-60.

Bellot, A., 1985. Etude gravimétrique du Rif paléozoïque : la forme du massif des BeniBoussera. Thèse Doct. ing., USTL Montpellier. Bezzeghoud, M., Dimitrov, D., Ruegg, J.C. \& Lammali, K., 1995. Faulting mechanism of the

\section{Tectonophysics 249, 249- 266.}

342 Bosch, M., Guillen, A., and Ledru, P., 2001. Lithologic tomography: An application to geophysical data from the Cadomian belt of northern Brittany, France. Tectonophysics, 331, 197-227.

Boschetti, F., Therond, V., Hornby, P., 2004. Feature removal and isolation in potential field data, Geophys. J. Int., 159, 833-841, doi:10.1111/j1365-246X.2004.02293.x. 
Boukerbout, H., Gibert, D., Sailhac, P., 2003. Identification of sources of potential fields with the continuous wavelet transform: Application to VLF data, Geophys. Res. Lett., 30(8), 1427, doi: 10.1029/2003GL016884.

Boukerbout, H., and Gibert, D., 2006. Identification of sources of potential fields with the continuous wavelet transform: Two-dimensional ridgelet analysis. Journal of Geophysical Research, Vol. 111, B07104, doi: 10.1029/2005JB004078.

Boukerbout, H., Abtout, A., \& Gibert, D. 2008. Interpretation of aeromagnetic data in the Chlef region (Algeria) using the wavelet transform in the case 3-D. Third International scientific and practical Conference and exhibition EAGE. European Association of Geoscientists and Engineers. Saint Petersburg, Russia.

Candès, M., 1998. Ridgelets: Theory and Applications. Ph.D. thesis, Dep. Of Stat., Stanford Univ., Stanford, Calif.

Chiarabba, C., Amato, A. \& Meghraoui, M. (1997). Tomographic images of the El Asnam fault zone and the evolution of a seismogenic thrust-related fold. Journal of geophysical Research., 102(B11), 24,485-24,498, doi:10.1029/97JB01778

Cuer, M., and Bayer, R., 1980. Fortran routines for linear inverse problems. Geophysics, 45, 1706-1719.

Debeglia, N., and Corpel, C., 1997. Automatic 3-D interpretation of potential field data using analytic signal derivatives. Geophysics, 62, 87-96.

Derder, M.E.M., Henry, B., Amenna M., Bayou B., Maouche S., Besse J., Ayache M., 2011.

Bloc rotation tectonics recorded in the Miocene magmatic rocks of "Beni Haoua" area (northern Algeria): preliminary paleomagnetic results. European Geosciences Union, General Assembly 2010, Vienna, Austria.

Fedi, M., Premiceri, R., Quarta, T., Villani, A. V., 2004. Joint application of continuous and discrete wavelet transform on gravity data to identify shallow and deep sources. Geophys. J. Int., 156, 7-21, doi:10.1111/j1365-246X.2004.02118.x.

Galdeano, A., Courtillot, V., Leborgne, E., Le Mouël J.L. \& Rossignol J.C., 1974. An aeromagnetic survey of the southwest of the western Mediterranean: description and tectonic implications. Earth Planet. Sci. Lett., 23, 323-336.

Gerard, A., and Griveau, P., 1972. Interprétations quantitatives en gravimétrie et magnétisme à partir de cartes transformées de gradient vertical. Geophys. Prospect. 20, 459-481.

Gourinard, Y., 1958. Recherche sur la géologie du littoral Oranais. - Thèse es Science, Service de la carte géologique de l'Algérie, Alger, $200 \mathrm{p}$.

Groupe de Recherche néotectonique de l'arc de Gibraltar, 1977. L'histoire tectonique récente (Tortonien à Quaternaire) de l'Arc de Gibraltar et des bordures de la mer d'Alboran. Bull. Soc. Géol. France, XIX, 3, 575-614.

Hartman, R. R., Teskey, D.J., and Friedberg, J.L., 1971. A system for rapid digital aeromagnetic interpretation. Geophysics, 36, 891-918.

Hatzfeld, D., 1978. Etude sismotectonique de la zone de collision ibéro-maghrébine. Thèse d'Etat, Univ. Grenoble I, 281 p.

Holshneider, M., 1995. Wavelets: An analysis tool. 423 pp., Clarendon, Oxford U.K.

Hornby, P., Boschetti, F., Horovitz, F.G., 1999. Analysis of potential field data in the wavelet domain, Geophys. J. Int., 137, 175-196. 
390 Hsu, S.K., Coppens, D., and Shyu, C.T., 1998. Depth to magnetic source using the 391 generalized analytic signal. Geophysics, 63, 1947-1957.

392 Huang, D., 1996. Enhancement of automatic interpretation techniques for recognizing 393 potential field sources. PhD thesis, Univ. of Leeds.

394 Idres, M., Ydri, A. \& Lefort, J.P. 1996. Proposition d'un schéma structural du bassin du Chélif 395 (Algérie) à partir de données gravimétriques. Comptes Rendus de l'Académie des Sciences 396 Paris, 322, IIa, 85-91.

397 Idres, M., Lefort, J.P., Aïfa, T., 1998. Modélisations gravimétriques et magnétiques des 398 structures profondes du bassin du Chélif (Algérie). Bulletin du Service Géologique de 399 l'Algérie, 9, 1, 21-32.

400 Keating, P.B., 1998. Weighted Euler deconvolution of gravity data. Geophysics, 63, 15954011603.

402 Kireche, O., 1977. Etude géologique structurale des massifs de la plaine du Chélif (Doui, 403 Rouina, Temoulga). Thèse Doct. $3^{\grave{e}}$ cycle, USTHB, Alger (Algérie).

404 Li, Y., and Oldenburg, D.W., 1996. 3-D inversion of magnetic data. Geophysics, 61, 394-408. 405 Mallat, S., 1999. A wavelet tour of signal processing. $2^{\text {nd }}$ Edition. Academic Press, 629 pp. 406 ISBN 0-12-466606-X.

407 Marson, I., and Kligele, E.E., 1993. Advantagesof using the vertical gradient of gravity for 3408 D interpretation. Geophysics, 58, 1588-1595.

409 Martelet, G., Sailhac, P., Moreau, F., Diament, M., 2001. Characterization of geological 410 boundaries using 1-D wavelet transform on gravity data: Theory and application to the 411 Himalayas. Geophysics, 66, 1116-1129.

412 Mattauer, M., 1958. Etude géologique de l'Ouarsenis oriental, Algérie. Publ. Serv. Carte 413 Géol. Algérie, 758.

414 McDonald, A.J.W., Fletcher, C.J.N., Carruthers, R.M., Wilson, D., Evans R.B., 1992. 415 Interpretation of the regional gravity and magnetic surveys of Wales, using shaded relief and 416 Euler deconvolution techniques. Geol. Mag. 129 (5), pp. 523-531.

417 Meghraoui, M. (1982). Etude néotectonique de la région nord-est d'El-Asnam: relation avec 418 le séisme du 10 octobre 1980. 3th cycle thesis, Paris7 Univ., pp 210.

419 Meghraoui, M., Cisternas, A. \& Philip, H. (1986). Seismotectonics of the lower Chelif basin: 420 structural background of the El-Asnam (Algeria) earthquake. Tectonics, 5, 6, 809-

421836.

422 Meghraoui, M. (1988). Géologie des zones sismiques du nord de l'Algérie: Paléosismologie, 423 tectonique active et synthèse sismotectonique. Doct. Sci. Thesis, Univ. Paris XI, $424356 \mathrm{pp}$.

425 Meghraoui, M., Morel J.L., Andrieux J. \& M. Dahmani., 1996.Tectonique plio-quaternaire de 426 la chaîne tello-rifaine et de la mer d'Alboran. Une zone complexe de convergence 427 continent-continent. Bulletin de la Société Géologique de France, 167, 1, 141-157.

428 Mikhailov, V., Galdeano, A., Diament, M., Gvishiani, A., Agayan, S., Bogoutdinov, S., 429 Graeva, E., P. Sailhac, 2003. Application of artificial intelligence for Euler solutions 430 clustering. Geophysics, 68, 168180, doi:10.1190/1.1543204.

431 Minster, J.B., Jordan, J.H., 1978. Present-day plate motions. J. Geophys. Res., 83, 5331-5354.

432 Moreau, F., Gibert, D., Holschneider, M., Saracco, G., 1997. Wavelet analysis of potential 433 fields, Inverse Probl., 13, 165-178. 
434

435

436

437

438

439

440

441

442

443

444

445

446

447

448

449

450

451

452

453

454

455

456

457

458

459

460

461

462

463

464

465

466

467

468

469

470

471

472

473

474

475

476

Moreau, F., Gibert, D., Holschneider, M., Saracco, G., 1999. Identification of sources of potential fields with the continuous wavelet transform: Basic theory, J. Geophys. Res., 104, 5003-5013.

Morel, J.L. \& Meghraoui, M., 1996. Goringe-Alboran-Tell tectonic zone; a transpression system along the Africa-Eurasia plate boundary. Geology, 1996, 24, 8, 755-758.

Nabighian, M.N., 1972. The analytic signal of two-dimensional magnetic bodies with polygonal cross-section. Geophysics, 37, 507-517.

Nabighian M.N., Grauch, V.J.S., Hansen, R.O., 2005. The historical development of the magnetic method in exploration. Geophysics, 70, 33-61.

Ouyed, M., Meghraoui, M., Cisternas, A., Deschamp, A., Dorel, J., Frechet, F., Gaulon, R.,

Hatzfeld, D. \& Philip, H. 1981. Seismotectonics of the El Asnam earthquake. Nature, 292, 5818, 26-31.

Parker, R.L., 1994. Geophysical Inverse Theory. Princeton Univ. Press, Princeton, N.J. Perrodon, A., 1957. Etude géologique des bassins néogènes sublittoraux de l'Algérie du Nord occidental. Publications du service de la carte géologique de l'Algérie, 12, 343.

Peters, L. J., 1949. The direct approach to magnetic interpretation and its practical application. Geophysics, 14, 290-320.

Philip, H. \& Meghraoui, M., 1983. Structural analysis and interpretation of the surface

deformations of the El-Asnam earthquake of October 10, 1980. Tectonics, 2, 1, 17-49.

Philip, H., Thomas, G., 1977. Détermination de la direction de raccourcissement de la phase de compression quaternaire en Oranie (Algérie). Rev. Géogr. Phys. Géol. dyn., 19, (4), 315324.

Pilkington, M., 1997. 3-D magnetic imaging using conjugate gradients. Geophysics, 62, 11321142.

Pilkington, M., and Keating, P., 2006. The relationship between local wavenumber and analytic signal in magnetic interpretation. Geophysics, 71, 1.1-1.3, doi:10.1190/1.2163911.

Reid, A.B., Allsop, J.M., Granser H., Millet, A.J., and Somerton, I.W., 1990. Magnetic interpretation in three dimensions using Euler deconvolution. Geophysics, 55, 80-91.

Roest, W.R., Verhoef, J., and Pilkington, M., 1992. Magnetic interpretation using the 3-D analytic signal. Geophysics, 57, 116-125.

Sailhac, P., Galdeano, A., Gibert, D., Moreau, F., Delor, C., 2000. Identification of sources of potential fields with the continuous wavelet transform: Complex wavelets and application to aeromagnetic profiles in French Guiana. J. Geophys. Research, 105, 19455-19475.

Sailhac, P., Gibert, D., 2003. Identification of sources of potential fields with the continuous wavelet transform: Two-Dimensional wavelets and multipolar approximation, J. Geophys. Res., 108(B5), 2262, doi: 10.1029/2002JB002021.

Sailhac, P., Gibert, D., Boukerbout, H., 2009. The theory of the continuous wavelet transform in the interpretation of potential fields: a review. Geophysical Prospecting, Vol. 57, No. 4. pp. 517-525.

Salem A., Ravat, D., Smith, R.S., and Ushijima, K., 2005. Interpretation of magnetic data using an enhanced local wavenumber (ELW) method. Geophysics, 70, no. 2, 7-12.

Salem, A., Williams, S., Fairhead, D., Smith, R.S., and., Ravat, D., 2008. Interpretation of magnetic data using tilt-angle derivatives. Geophysics, 73, 1-10. 
Smith, R.S., Thurston, J.B., Dai, T., and Macleod, I.N., 1998. iSPI - The improved source parameter imaging method. Geophysical Prospecting, 46, 141-151.

Smith, R.S., and Salem, A., 2005. Imaging depth, structural and susceptibility from magnetic data: The advanced source-parameter imaging method. Geophysics, 70, no. 4, 141-151. Stavrev, P.Y., 1997. Euler deconvolution using differential similarity transformations of gravity or magnetic anomalies. Geophys. Prosp., 45, 207-246.

Tass, P., Rosemblum, M. G., Weule, J., Kurths, J., Pikovsky, A., Volkmann, J., Schnitzler, A., Freund, H.-J., 1998. Detection of n:m phase locking from noisy data: application to magneto encephalography. Phys. Rev. Lett., 81, 3291-3294.

Tarantola, A., 1987. Inverse Problem Theory. Elsevier, New York.

Thomas, G. 1985. Géodynamique d'un bassin intra montagneux: le bassin du bas Chéliff occidental (Algérie) durant le Mio-Plio-Quaternaire. Doct. Sci. Thesis, Univ. de Pau, France.

Thompson, D. T., 1982. EULDPH: A new technique for making computer-assisted depth estimates from magnetic data. Geophysics, 47, 31-37.

Thurston, J.B., and Smith, R.S., 1997. Automatic conversion of magnetic data to depth, dip and susceptibility contrast using the SPI method. Geophysics, 62, 807-813.

Thurston, J.B., Smith, R.S., and Guillon, J., 2002. A multi-model method for depth estimation from magnetic data. Geophysics, 67, 555-561.

Torresani, B., 1995. Analyse continue par ondelettes. InterEditions \& CNRS Editions, Paris. 239 pp. ISBN 2-7296-0591-6.

Vallée, M.A., Keating, P., Smith, R.S., and St-Hilaire, C., 2004. Estimating depth and model type using the continuous wavelet transform of magnetic data. Geophysics, 69, 191-199.

Van Den Bosch, J.W.H., 1971. Carte gravimétrique du Maroc au 1/500000, Anomalie de Bouguer d = 2.67. - Notes et Mém. Serv. Géol. Maroc, $n^{\circ} 234$.

Werner, S., 1953. Interpretation of magnetic anomalies at sheet-like bodies. Serviges Geologiska Undersok, Ser. C, 43, N06.

\section{List of figures}

Figure 1. Localization and geological setting of the Cheliff region (modified from Meghraoui, 1988). The studied area (four-sided white figure) is located in a box ranging from $01^{\circ}$ $01^{\circ} 46^{\prime}$ in longitude and $36^{\circ}-36^{\circ} 36^{\prime}$ in latitude.

Figure 2. Seismotectonic map of the NW of Algeria.

Figure 3. The Bouguer anomaly map of the studied area based on $0.25 \mathrm{~km}$ grid spacing of data reduced with density of $2.400 \mathrm{~kg} \mathrm{~m}^{-3}$.

Figure 4. Shaded map of the Bouguer anomaly. This map enhances more details that not appear on the Bouguer map and, allow a best correspondence with geological features.

.Figure 5. The residual map of the Bouguer anomaly, showing shallow known and unknown contacts between geological structures with contrasting densities. 
516 Figure 6. Vertical gradient of the Bouguer anomaly. High frequency anomalies are visible in 517 the Cheliff basin corresponding to faults and contacts.

518 Figure 7. Upward continuation at $3 \mathrm{~km}$ of the Bouguer anomaly showing large wavelengths.

519 The most negative anomalies within the basin disappear on the upward continued map at $3 \mathrm{~km}$

520 Figure 8. 3-D image of identified structures located by ridgelet analysis of the gravity 521 anomalies. The North direction is given by the latitude axis. The colour scale corresponds to 522 the maximum entropy criteria (Tass et al., 1998; Boukerbout et al., 2003; Boukerbout and 523 Gibert, 2006; Sailhac et al., 2009) for selecting sources location.

524 Figure 9. Summary of the different gravimetric features outlined from different analyzing methods reported on the shaded map: in white those identified from residual and vertical gradient; in colour those identified from ridgelet analysis which are represented by an image plane of the perspective on Figure 8.

528 Figure 10. Correlation between gravimetric identified structures from different analysis methods and the seismicity map of the studied area. The identified structures such as summarized on Figure 9, are superimposed on the seismicity map to do the correlation. 


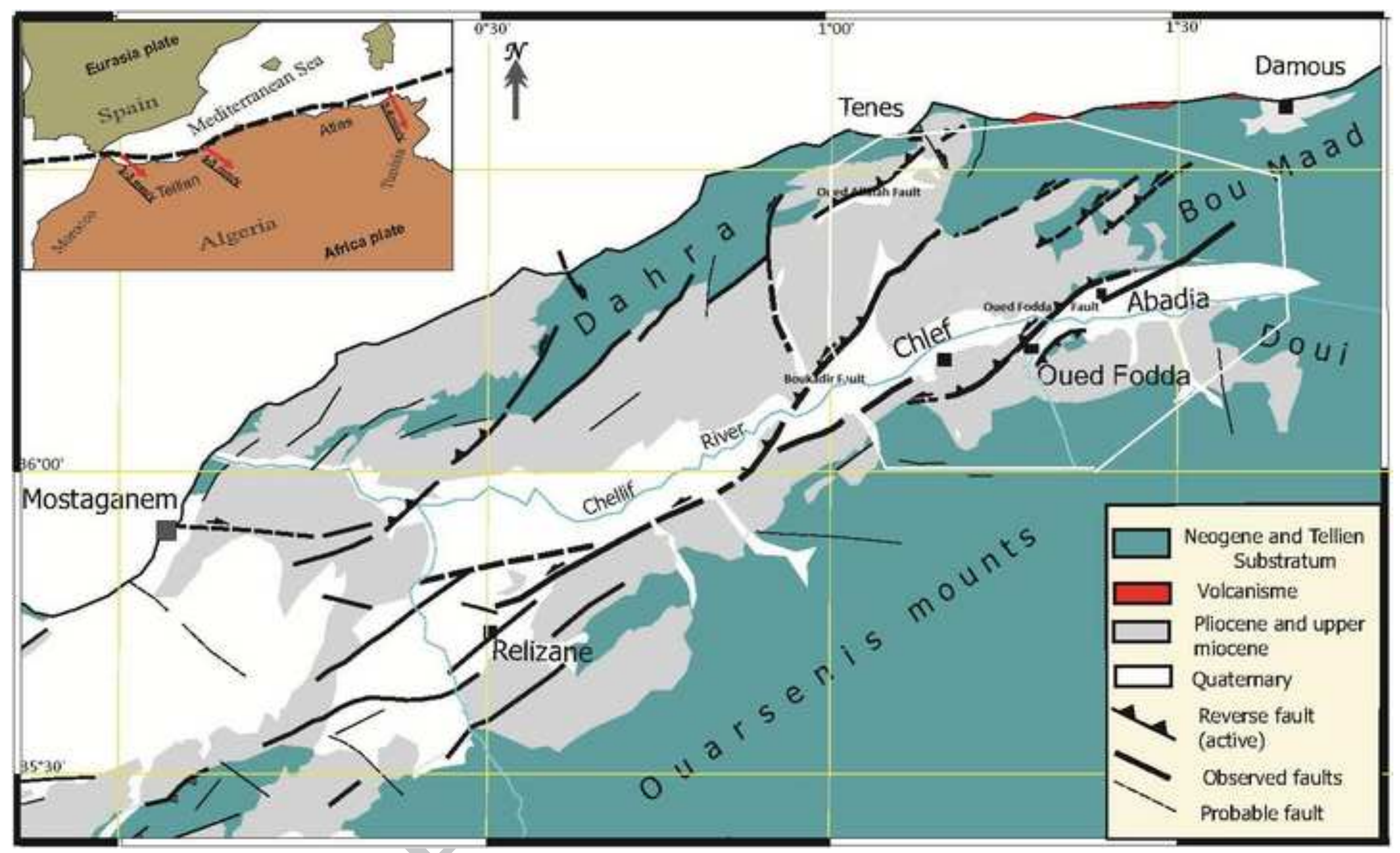




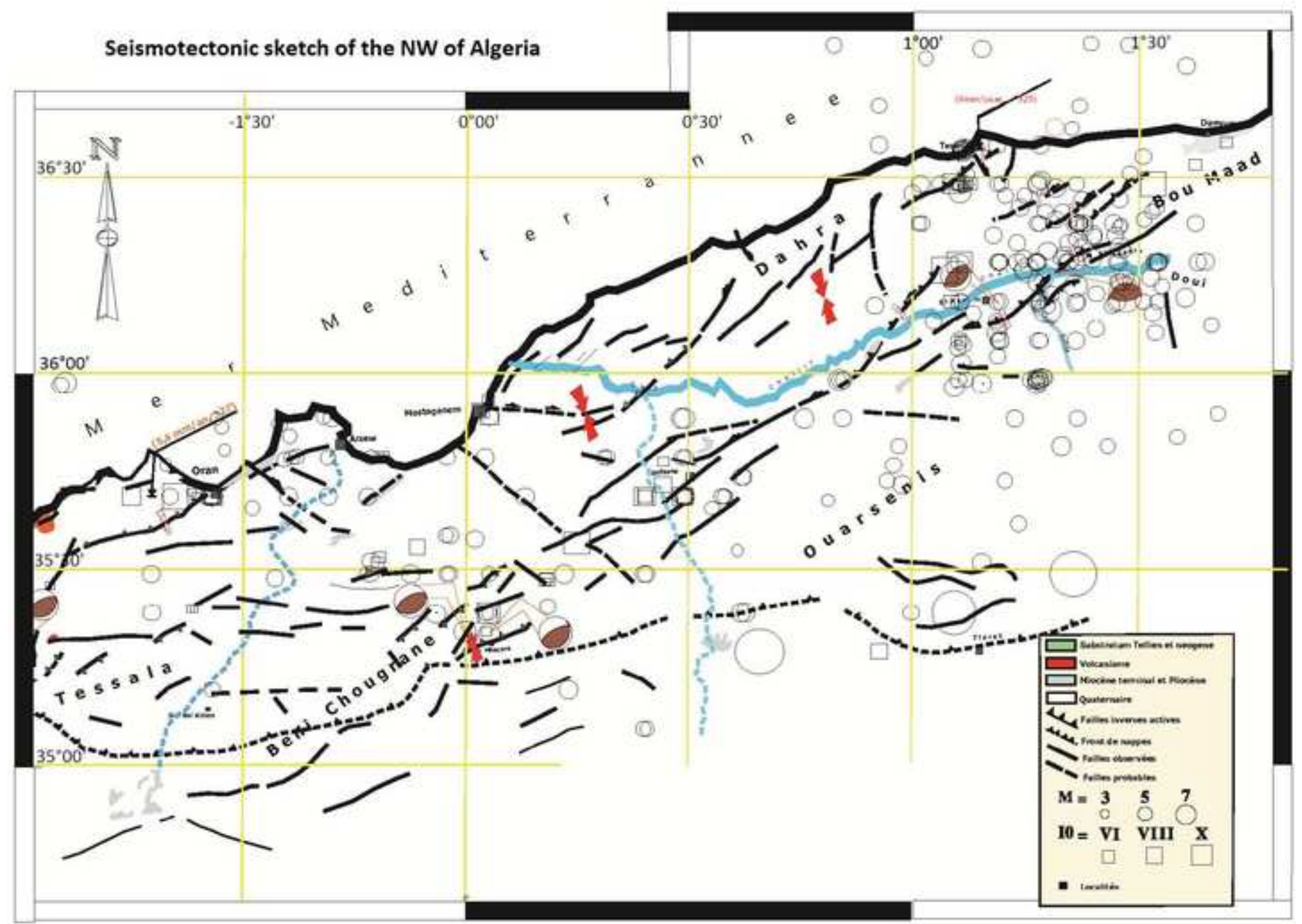


ACCEPTED MANUSCRIPT

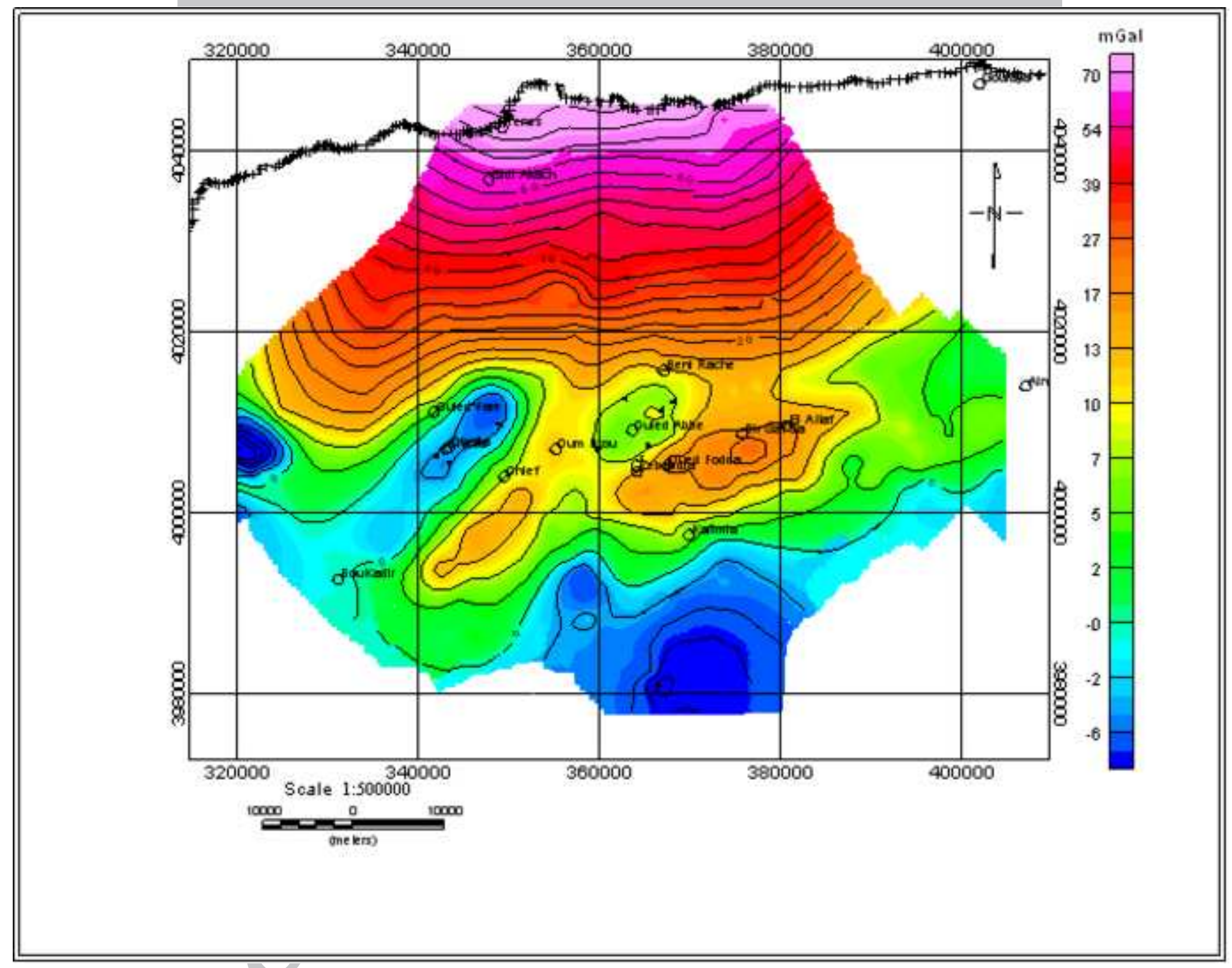




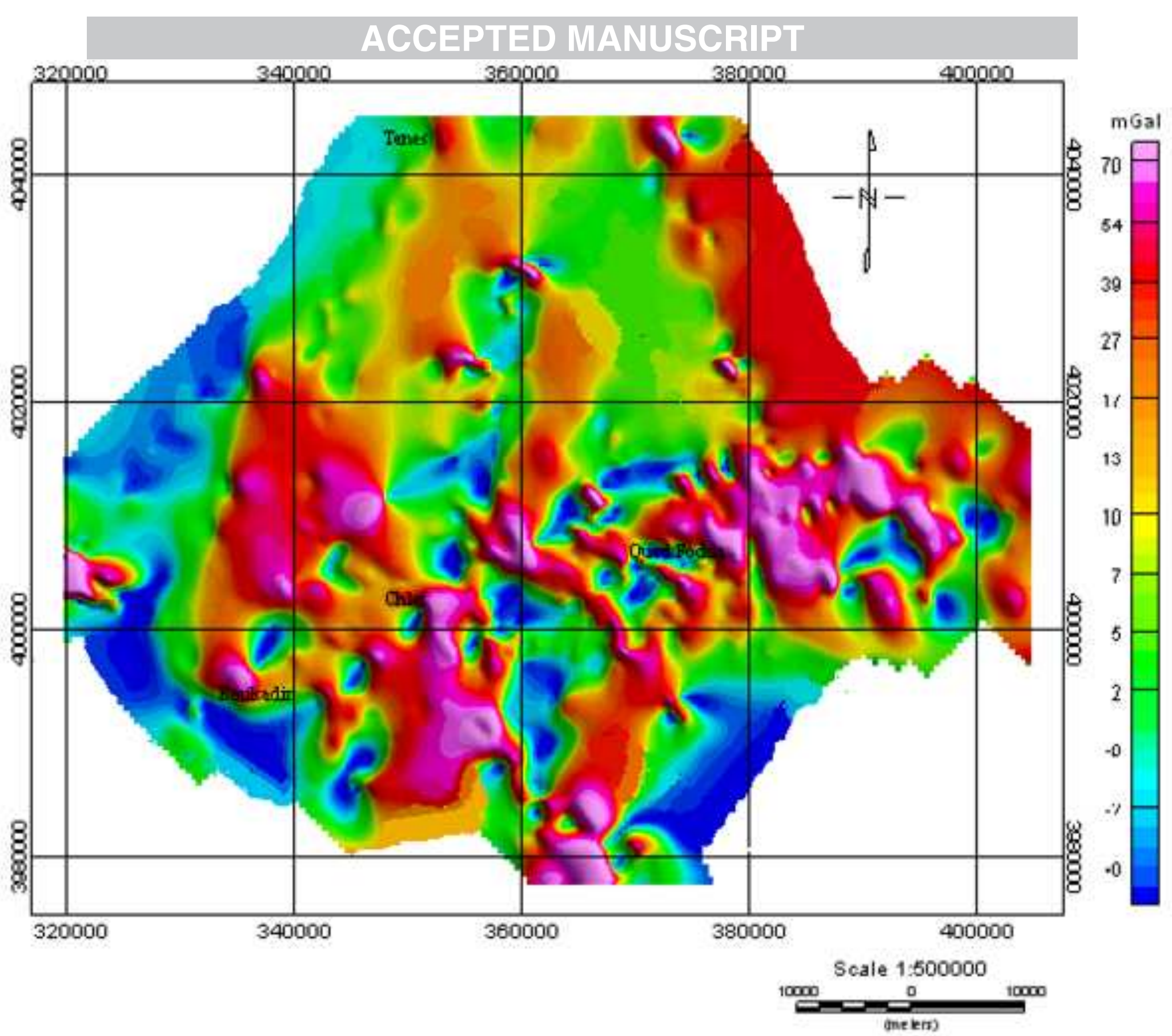




\section{ACCEPTED MANUSCRIPT}

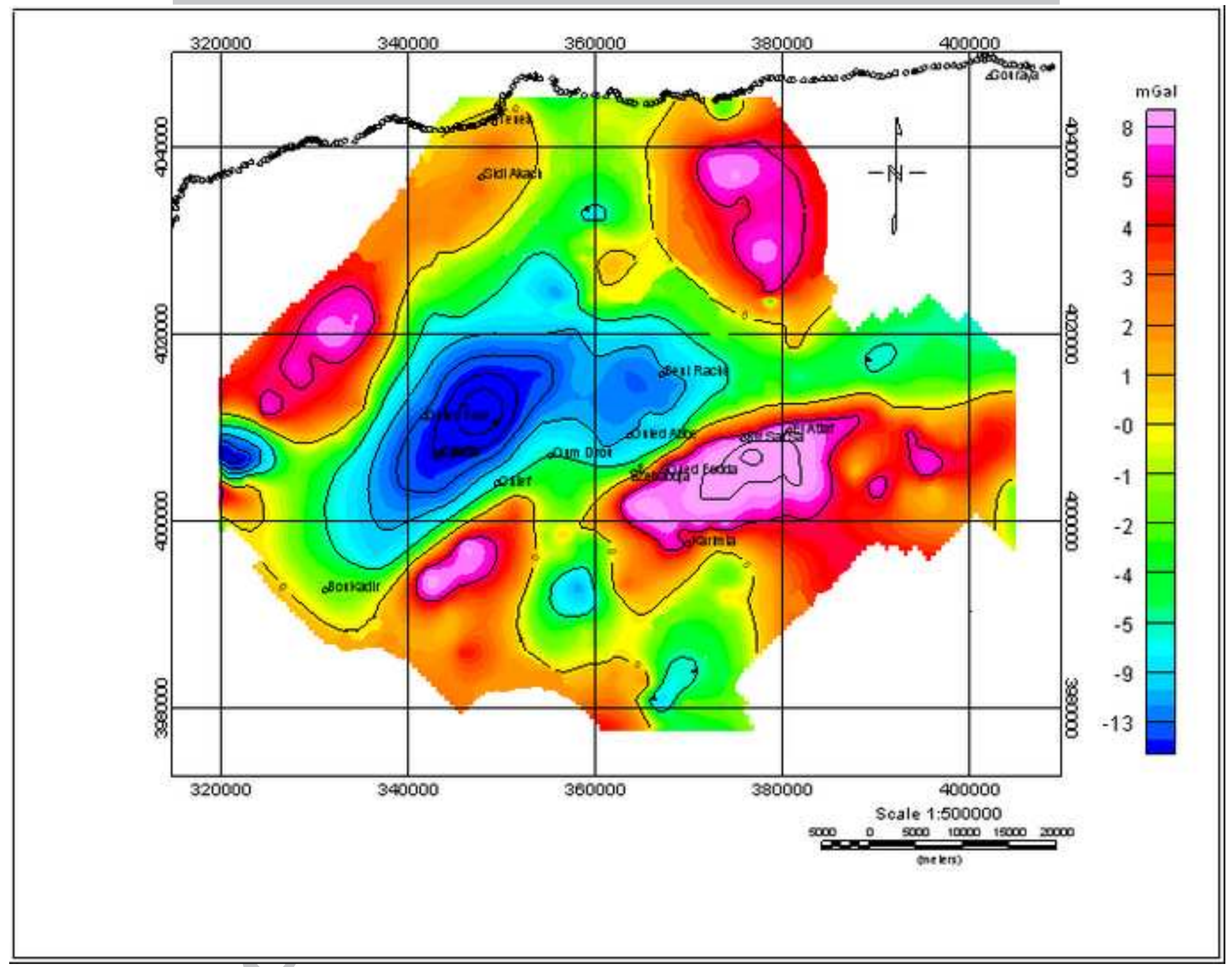


ACCEPTED MANUSCRIPT

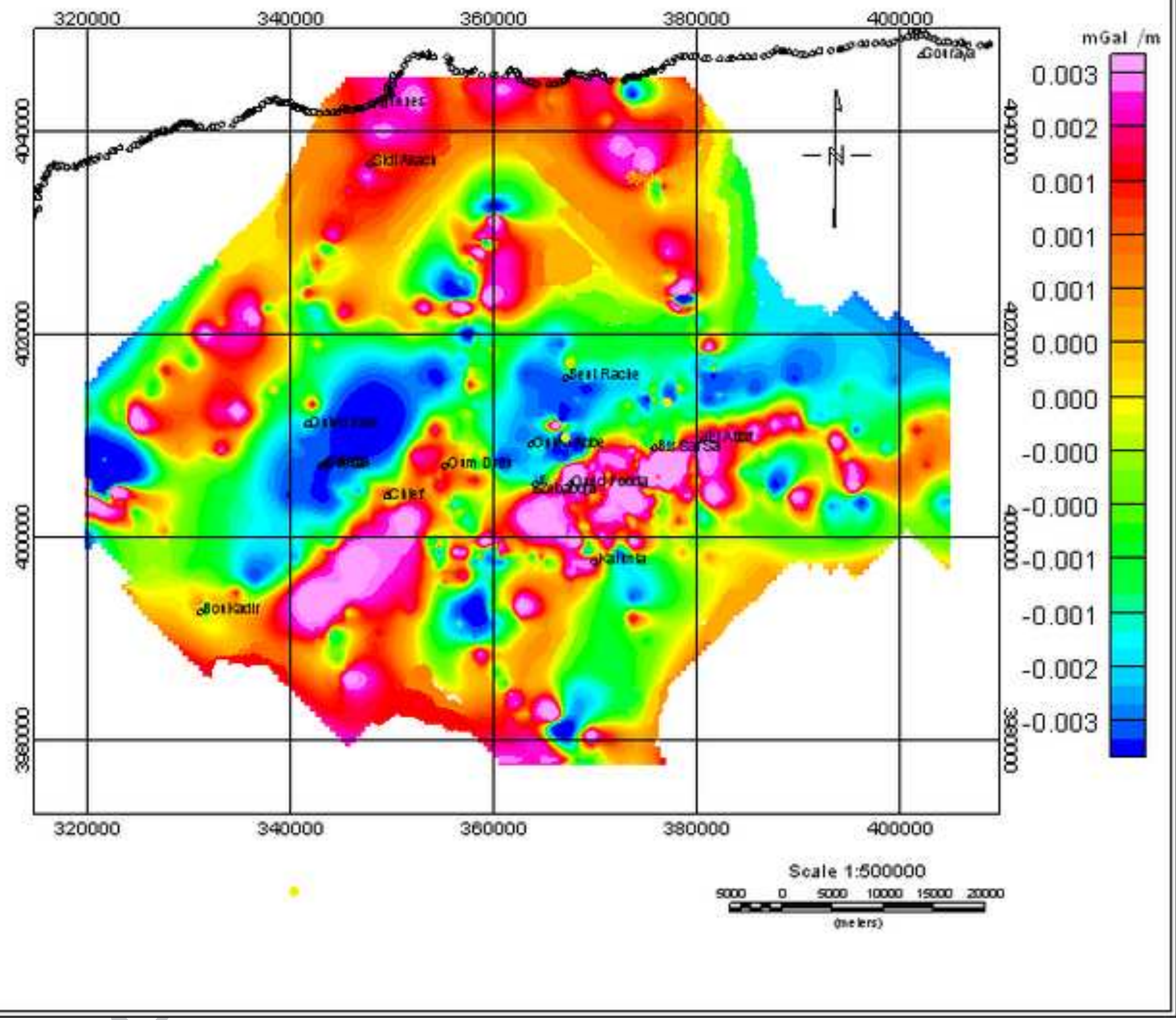


ACCEPTED MANUSCRIPT

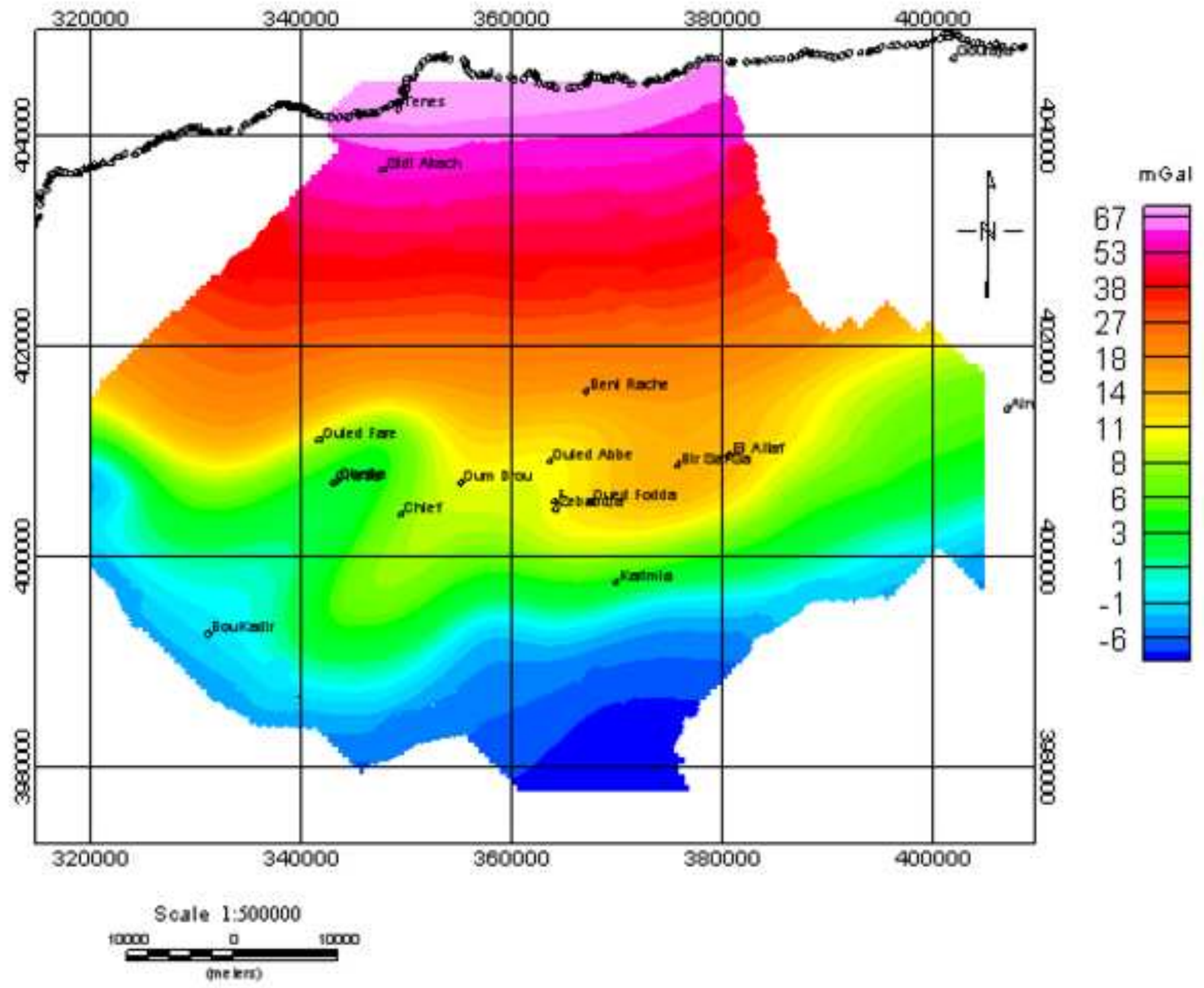




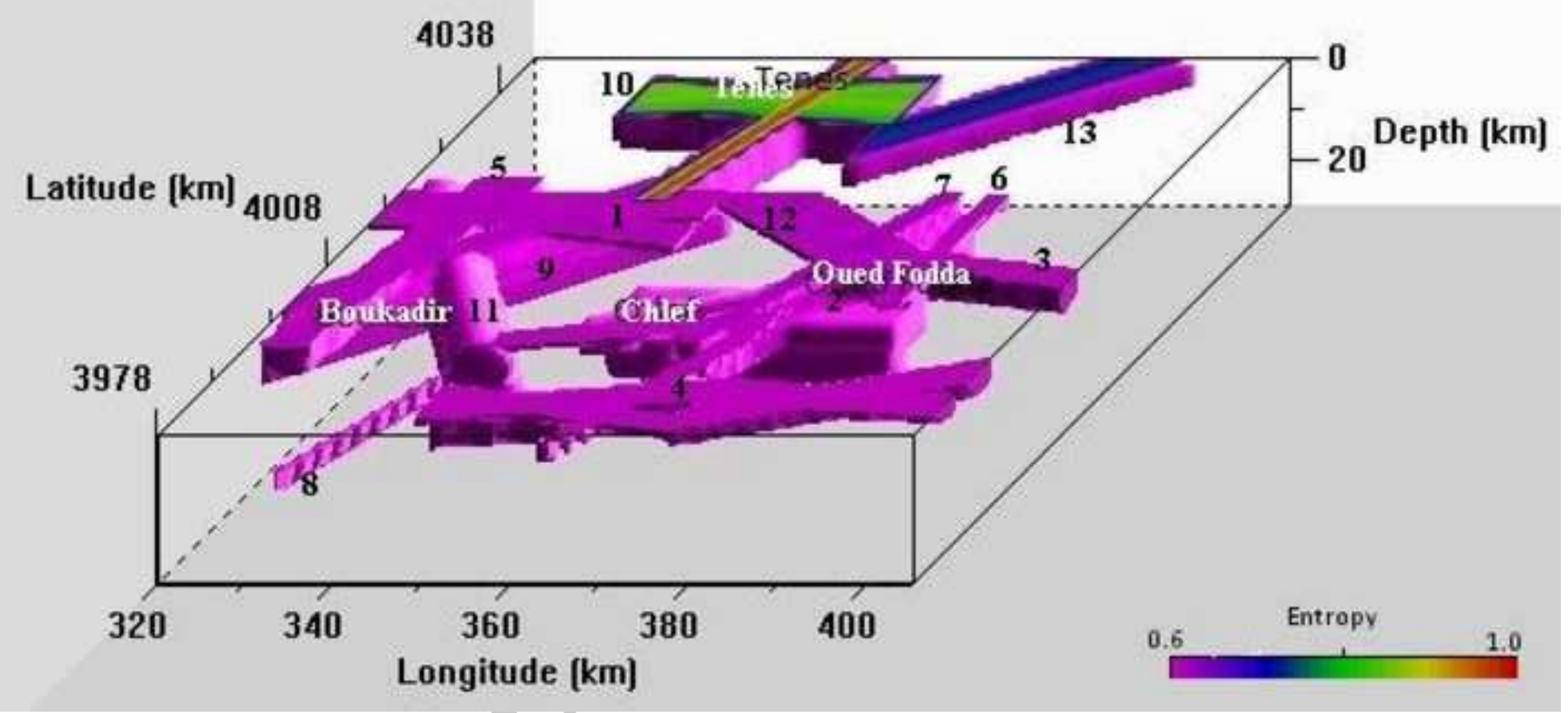




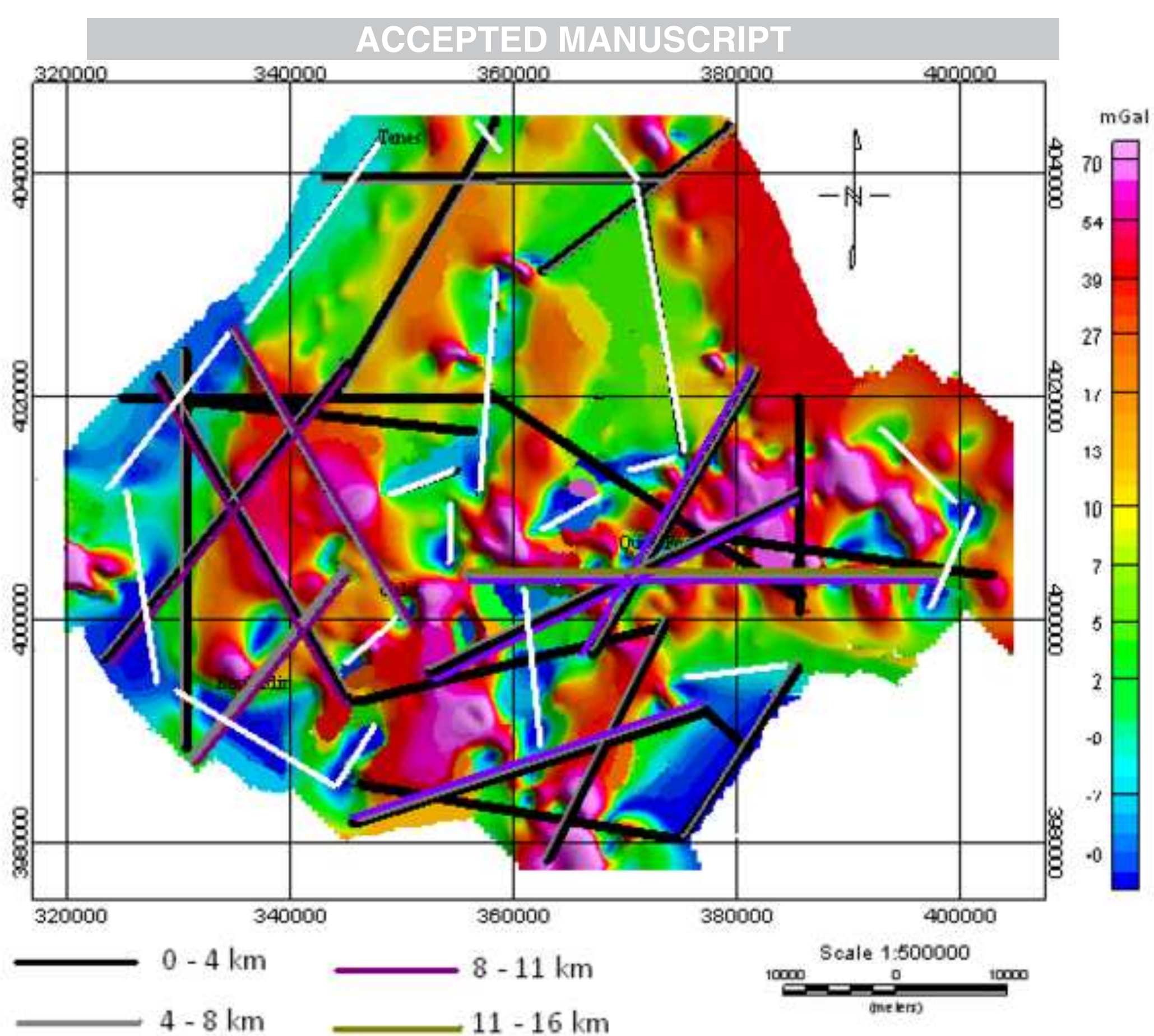


ACCEPTED MANUSCRIPT

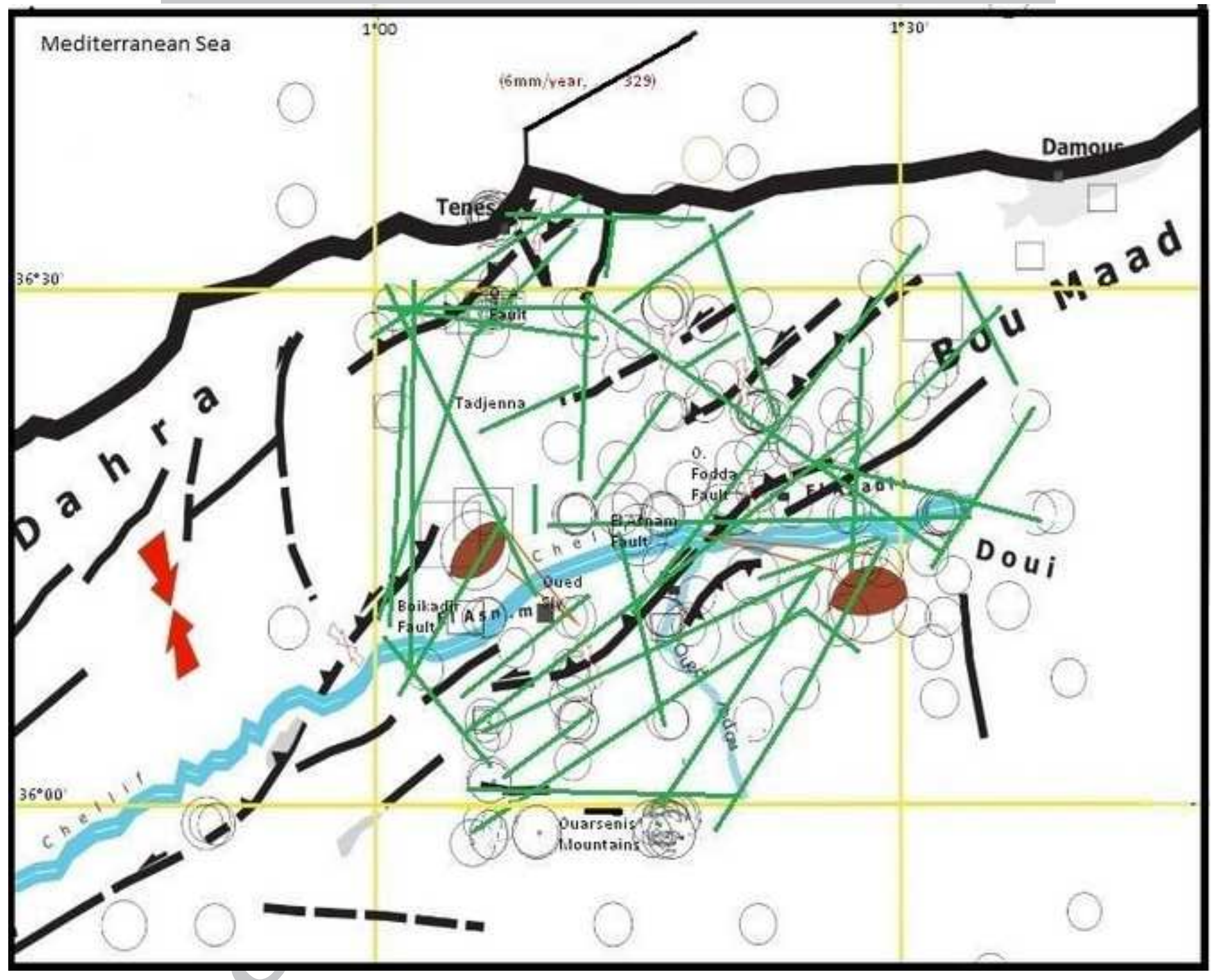




\section{Highlights}

We study gravity anomalies of the seismogenic Cheliff region in Algeria.

We use different processing methods to highlight long and short wavelength.

We use the continuous wavelet transform to identify deep anomalies causative bodies.

We establish the 3-D image of Cheliff basin

A correlation between geological, seismotectonic data and gravity features is done. 